\title{
Understanding aerosol formation mechanisms in a subtropical atmosphere impacted by biomass burning and agroindustry
}

\author{
Michele L. Souza, Andrew G. Allen, Arnaldo A. Cardoso * \\ Department of Analytical Chemistry, Institute of Chemistry, São Paulo State University (UNESP), Araraquara, SP 14800-060, Brazil
}

\section{A R T I C L E I N F O}

\section{Article history:}

Received 13 May 2016

Received in revised form 11 August 2016

Accepted 22 August 2016

Available online 24 August 2016

\section{Keywords:}

Aerosols

Agro-industry

Homogeneous nucleation

Heterogeneous processes

Size distribution

\begin{abstract}
A B S T R A C T
This work provides evidence for the existence of strong seasonality in homogeneous and heterogeneous aerosol formation in a subtropical region affected by agricultural biomass burning. Acquisitions of aerosol size distributions were made in central São Paulo State between August 2011 and November 2012, using a scanning mobility particle sizer (SMPS) system. Aerosols were also collected using a high volume impactor for analysis of major ions in the $<0.49 \mu \mathrm{m}$ size fraction. The SMPS data were grouped into three size fractions: $<25 \mathrm{~nm}, 25-100 \mathrm{~nm}$, and 100-615 nm, which were used to represent the nucleation, Aitken, and lower accumulation mode size ranges, respectively. Different aerosol types and atmospheric conditions were shown to influence the relative contributions of the different aerosol size fractions and their interrelationships. The total number concentrations of particles in the nucleation size range varied between $4.03 \times 10^{-3}$ and $5.18 \times 10^{4} \mathrm{~cm}^{-3}$, concentrations in the Aitken size range varied between $1.60 \times 10^{1}$ and $3.17 \times 10^{4} \mathrm{~cm}^{-3}$, and concentrations in the accumulation size range varied between 0.00 and $6.67 \times 10^{3} \mathrm{~cm}^{-3}$. Distinct seasonal differences in particle formation were observed, with evidence for the preferential occurrence of homogeneous nucleation during the wetter summer months and heterogeneous nucleation during the winter when there were strong emissions from biomass burning. Homogeneous nucleation of new particles was inhibited in the winter, due to the greater surface area of existing aerosols available for the uptake of reactive gases. Consequently, the nucleation and Aitken modes were favored in the wet (summer) and dry (winter biomass burning) periods, respectively. The accumulation mode showed peaks in the summer and winter, which could be explained by hygroscopic particle growth and heterogeneous reactions, respectively.
\end{abstract}

(c) 2016 Elsevier B.V. All rights reserved.

\section{Introduction}

The relevance and role of atmospheric aerosols in the ambient environment are scientifically well established. Aerosols affect visibility and air quality, and have impacts on human health (Singh and Dey, 2012; Lei and Wuebbles, 2013; Kan et al., 2012). The particles can act as cloud condensation nuclei and also modify the heat transfer properties of the atmosphere, with consequent changes in cloud formation processes and alteration of rainfall patterns (Rosenfeld et al., 2008). The deposition of aerosols onto terrestrial and oceanic surfaces can increase the availability of nutrients and other species, and hence affect the biogeochemical cycles of various elements (Andreae and Crutzen, 1997). It is therefore essential to understand the mechanisms of formation of aerosols, as well as their subsequent behavior in the environment.

In the atmosphere, the formation of ultrafine particles can proceed according to either homogeneous or heterogeneous mechanisms. Homogeneous nucleation occurs when low vapor pressure gas phase molecules condense to form extremely small new particles, and is favored by low concentrations of existing particles. Examples of substances

\footnotetext{
* Corresponding author.

E-mail address: acardoso@iq.unesp.br (A.A. Cardoso).
}

that can undergo homogeneous nucleation processes are sulfuric acid $\left(\mathrm{H}_{2} \mathrm{SO}_{4}\right)$ and the oxidation products of hydrocarbons released into the atmosphere from natural and anthropogenic sources. In contrast, heterogeneous nucleation proceeds by condensation of molecules onto existing small particles, so that the latter grow in size. It is generally accepted that nucleation mode particles originate from homogeneous nucleation, while Aitken mode particles originate from the growth of nucleation mode particles by heterogeneous nucleation (Kulmala, 2003).

The aerosols observed in the atmosphere are the result of earlier emissions and/or in situ formation and growth, and the particles are eventually removed by deposition (Kulmala et al., 2004; Holmes, 2007; Allen et al., 2010). Secondary aerosols are formed by nucleation through a number of different mechanisms. The formation rates of new particles have been explained using the processes of ion-induced nucleation, binary nucleation (involving water and sulfuric acid), and ternary nucleation (sulfuric acid-ammonia-water) (Kulmala et al., 2000; Hegg et al., 1990; Korhonen et al., 1999; Laakso et al., 2002; Kulmala et al., 2013). Ternary nucleation yields thermodynamically stable clusters 1-3 nm in size. These particles grow due to coagulation with other particles, or by condensation of gas phase species, at a rate that is dependent on factors including particle size, chemical composition, concentration, and temperature (Vuollekoski et al., 2010). Studies of the 
smallest nucleation mode particles have been restricted to a few regions. For example, Kulmala et al. (2013) observed aerosol nucleation in a remote forest in Finland, using new analytical tools. However, information is lacking concerning the mechanisms of aerosol nucleation in many global regions.

Despite the increasing number of studies, understanding of particle formation and growth is largely limited to modeling exercises, rather than experimental observations (Holmes, 2007). Most of the available instrumentation is only able to detect particles larger than $3 \mathrm{~nm}$, which means that it is difficult to characterize the earlier stages of particle nucleation. It is possible that a reservoir of undetectable particles exists at all times in the atmosphere (Holmes, 2007). Furthermore, for many regions there is little information concerning the chemical composition of the finest atmospheric particles, often related to the fact that chemical methods require a minimum amount of material for analysis. The lack of chemical data is another limitation to understanding nucleation processes and the initial growth of particles.

In many regions worldwide, biomass burning is a major contributor to the atmospheric aerosol (Ichoku et al., 2012; Zhao et al., 2015; Zhu et al., 2016). The atmosphere of the region studied here is affected by widespread emissions from the burning of sugar cane, the most important agricultural crop, which for many years has had a dominant influence on aerosol chemistry during the winter dry (burning) season (Allen et al., 2004; Allen et al., 2010; Da Rocha et al., 2005; Urban et al., 2016).

In the present work, continuous measurements of aerosol number size distributions was used together with determinations of the chemical composition of the particles and meteorological parameters in order to understand the main factors affecting aerosol formation in a subtropical region affected by emissions from biomass burning and industrialized agriculture.

\section{Experimental}

\subsection{Ground-based measurements}

Measurements were made between August 2011 and November 2012 on the campus of São Paulo State University, in a rural location $\sim 4 \mathrm{~km}$ southwest of the town of Araraquara (site coordinates: $21^{\circ} 48^{\prime}$
50.3" S; $48^{\circ} 12^{\prime} 07.2^{\prime \prime} \mathrm{W}$; $658 \mathrm{~m}$ above sea level). Equipment was installed on the roof of a building at $\sim 5 \mathrm{~m}$ above the ground (Fig. 1). To the south of the site there was a clear fetch of $>30 \mathrm{~km}$ over sugar cane plantations. To the northeast were the UNESP campus and the Araraquara urban area.

The aerosol instrumentation comprised an electrostatic aerosol classifier (TSI Model 3080L) connected to a condensation particle counter (TSI Model 3775), operated in scanning mobility particle sizer (SMPS) configuration. Ambient aerosols were conveyed directly to the SMPS inlet through a short $(60 \mathrm{~cm})$ length of $8 \mathrm{~mm}$ i.d. copper tubing. Particle number concentrations in the size range 14.6-615.3 nm (selected using an impactor attached to the inlet of the instrument) were continuously recorded as 2-minute averages (acquired every $10 \mathrm{~min}$ ). In the following discussion, the terms "nucleation", "Aitken", and "accumulation" refer to particles with diameters $<25 \mathrm{~nm}, 25-100 \mathrm{~nm}$, and 100$615.3 \mathrm{~nm}$, respectively.

Seasonal differences in particle number concentrations were determined for the period starting in the winter of 2011 (dry period) and ending in the spring of 2012 (at the start of the rainy period). The seasons considered were: winter 2011 (August 11 to September 23); spring 2011 (September 23 to December 22); summer 2011/2012 (December 22, 2011 to March 20, 2012); autumn 2012 (March 20 to June 20); winter 2012 (June 20 to September 22); spring 2012 (September 22 to November 31 ).

\subsection{Bulk aerosol sampling}

Bulk aerosols were collected on a fortnightly basis using a highvolume sampler (Model TE-5000, Tisch Environmental), operated at a flow rate of $1140 \mathrm{~L} \mathrm{~min}^{-1}$, onto glass fiber filters (Whatman, $25.2 \times 20.2 \mathrm{~cm}$ ). The filters were used as received, without any pretreatment. Size-resolved samples for chemical analysis were collected using a six-stage (including backup filter) cascade impactor, with aerodynamic cutoffs for the individual stages of 7.2, 3.0, 1.5, 0.95, and $0.49 \mu \mathrm{m}$. The exposed filters were folded in half, wrapped in aluminum foil, and stored in plastic bags at $22^{\circ} \mathrm{C}$ for no longer than three months, until analyzed. In this work, only the fraction corresponding to particles in the size range $<0.49 \mu \mathrm{m}$ was used.

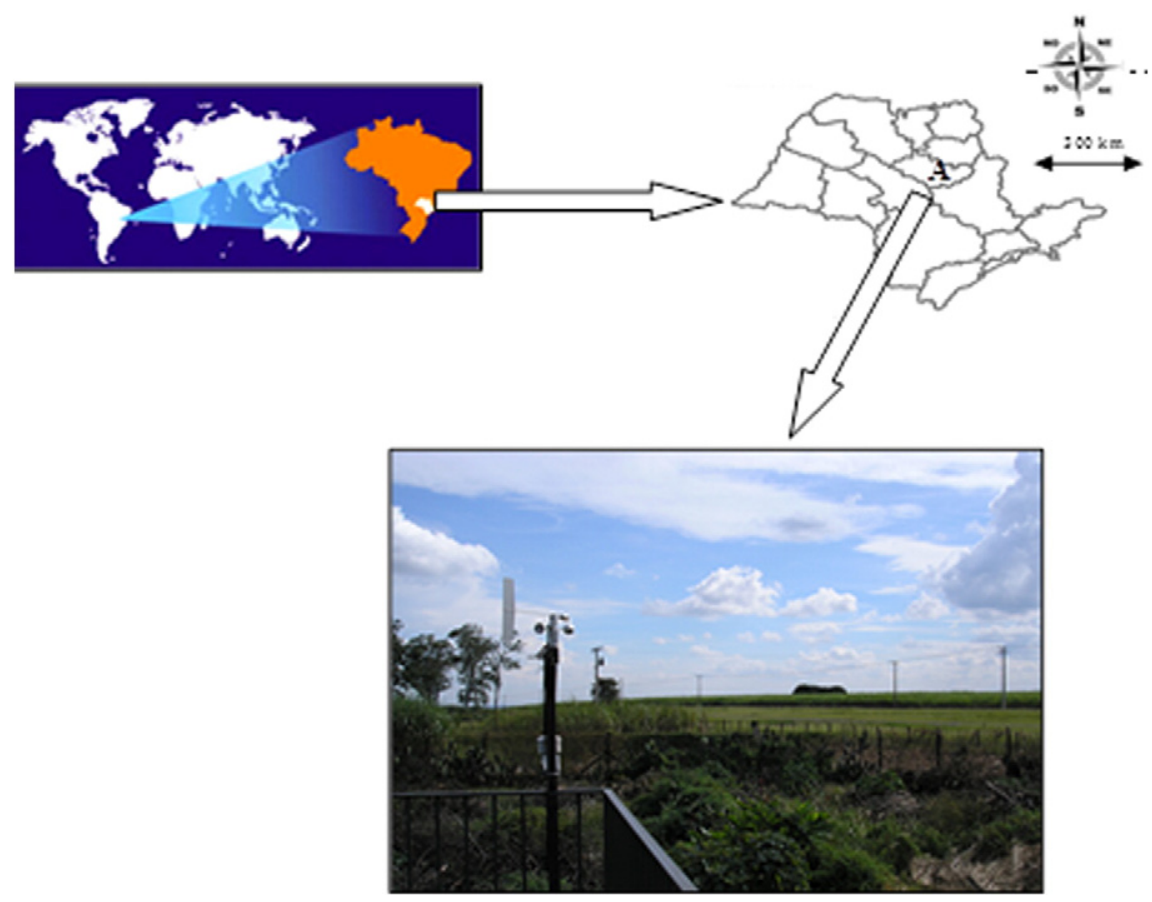

Fig. 1. Location of the measurement site (A) in São Paulo State. 


\subsection{Measurements of $\mathrm{NO}_{2}$ and $\mathrm{O}_{3}$}

Continuous measurements of $\mathrm{O}_{3}$ and $\mathrm{NO}_{\mathrm{x}}$ were carried out using Thermo Environment 49i and 42i instruments. The data were recorded every 10 min using a Campbell CR1000 datalogger.

\subsection{Detection of agricultural fires}

An indication of the intensity of biomass burning in São Paulo State was obtained from the monthly total number of fire foci detected by sensors on board the EOS, NOAA, GOES, and MSG satellites (historical data available at http://sigma.cptec.inpe.br/queimadas). These data provided an indication of relative fire frequency (not the absolute numbers of fires). The numbers of fires detected in São Paulo State in the years 2011 and 2012 are shown in Fig. 2.

\subsection{Air mass trajectories}

Backward air mass trajectories were calculated using the United States National Oceanic and Atmospheric Administration (NOAA) HYSPLIT 4 model (Hybrid Single-Particle Lagrangian Integrated Trajectory 4). The 24-h back-trajectories arrived at a height of $500 \mathrm{~m}$ above the ground.

\subsection{Meteorological conditions}

The meteorology of the study region is characterized by distinct seasonal differences. Summers are hot (average temperature of $29.6^{\circ} \mathrm{C}$ ) with frequent rainfall (average of $234.3 \mathrm{~mm}$ ) and intense insolation. In winter, temperatures are lower (average $26.1^{\circ} \mathrm{C}$ ), precipitation is low (average of $30.5 \mathrm{~mm}$ ), and humidity decreases, especially during the daytime (http://www.cepagri.unicamp.br/). The dry winter conditions favor the build-up of particles in the atmosphere (Allen et al., 2004). In the case of the intermediate seasons, autumn is usually drier than spring (average precipitation of 50.1 and $154.4 \mathrm{~mm}$, respectively).

The sampling site on the Araraquara campus of São Paulo State University was situated $\sim 1 \mathrm{~km}$ west of the urban limit of Araraquara city, defined by a highway that runs from northwest to southeast. Air masses arriving at the site typically pass over sugar cane plantations and cattle pasture, as well as built-up areas and roads. In the present work, consistent diurnal trends in wind direction were observed for all seasons, although wind speeds were higher in winter and spring (Fig. 3). The average diurnal trends in the intensity of solar radiation were similar

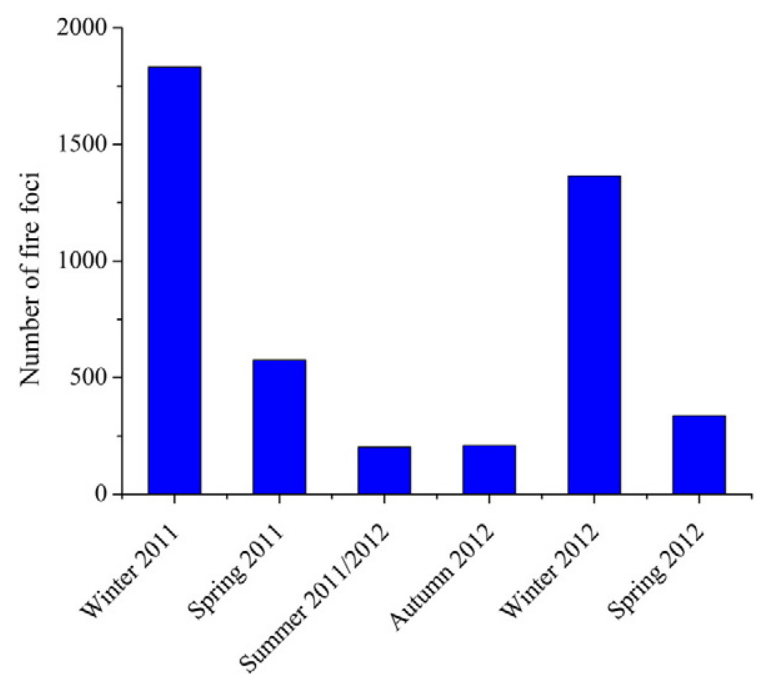

Fig. 2. Numbers of fire foci detected in São Paulo State for the years 2011 and 2012. for all seasons, with the exception of autumn 2012, when cloud cover and humidity were higher (Fig. 3).

In the study region, the main agricultural activity is the cultivation of sugar cane to produce sugar and ethanol biofuel, with the climatic conditions ensuring high crop productivity. The rainy period (summer) favors growth of the plants and is when most fertilizer applications are made, which increases emissions of reduced and oxidized gaseous compounds of nitrogen (Allen et al., 2004; Machado et al., 2008).

The sugar cane is harvested between April and November, using both mechanized and manual methods. In 2012, $72.60 \%$ of the cane was harvested mechanically (UNICA, 2013). In areas where the manual technique is employed, the agricultural practice requires previous burning of the sugar cane straw (outer leaves) in order to eliminate venomous animals and improve the efficiency of manual cutting and transport. The burning practice results in emissions to the atmosphere of large quantities of gases and particles, and both harvesting methods are associated with substantial emissions of soil dusts (Da Rocha et al., 2003; Allen et al., 2004).

\section{Results and discussion}

\subsection{Seasonal variability of aerosol number size distributions}

During the measurement period, the total number concentrations of particles in the nucleation size range varied between $4.03 \times 10^{-3}$ and $5.18 \times 10^{4} \mathrm{~cm}^{-3}$, concentrations in the Aitken size range varied between $1.60 \times 10^{1}$ and $3.17 \times 10^{4} \mathrm{~cm}^{-3}$, and concentrations in the accumulation size range varied between 0.00 and $6.67 \times 10^{3} \mathrm{~cm}^{-3}$.

The average aerosol number size distributions determined for the spring of 2011, the summer of 2011/2012, and the autumn of 2012 showed that the numbers of particles in the nucleation size range exceeded the number of Aitken mode particles. In contrast, during the winter periods, the opposite behavior was observed, with the Aitken mode predominating (Fig. 4).

The number concentrations of nucleation mode particles increased in the summer, reaching a maximum in 2012. This suggested that conditions during the summer favored the homogeneous nucleation of new particles. The accumulation mode showed a maximum in the summer in 2012 and in the winter (2012). The first of these could be explained by greater hygroscopic particle growth in summer, as reported previously (Caetano-Silva et al., 2013), and the second by greater particle formation due to heterogeneous reactions in the winter. Seasonal trends of the Aitken mode particle number concentrations were less clear, although there was evidence of both summer and winter maximum in number concentrations.

The processes of particle nucleation and growth therefore varied during the course of the year, with the nucleation and Aitken modes being favored in the wet (summer) and dry (biomass burning) periods, respectively. Atmospheric conditions during the summer enabled substantial new particle formation, which was lower during the intermediate periods (spring and autumn) and was largely replaced by the growth of existing particles in the winter.

The particle number size distributions obtained for the different seasons are shown in Fig. 5. Previous work has shown that during the winter biomass burning period, large quantities of primary aerosols are emitted to the atmosphere, while at the same time there are strong emissions of reactive gases such as $\mathrm{HNO}_{3}, \mathrm{SO}_{2}, \mathrm{NO}_{2}, \mathrm{NH}_{3}$, and organic acids (Allen et al., 2004; Da Rocha et al., 2005). The findings therefore indicate that these primary aerosols, together with any secondary aerosols formed, were able to absorb reactive gas phase species, which then became unavailable for the formation of new particles. This mechanism is able to explain the predominance of the Aitken mode in the aerosol number size distribution in the dry (sugar cane burning) season, since this mode is known to arise from processes of gas condensation (Kulmala et al., 2000). In contrast, during summer, the much smaller quantity of primary aerosols enabled the nucleation of new secondary 

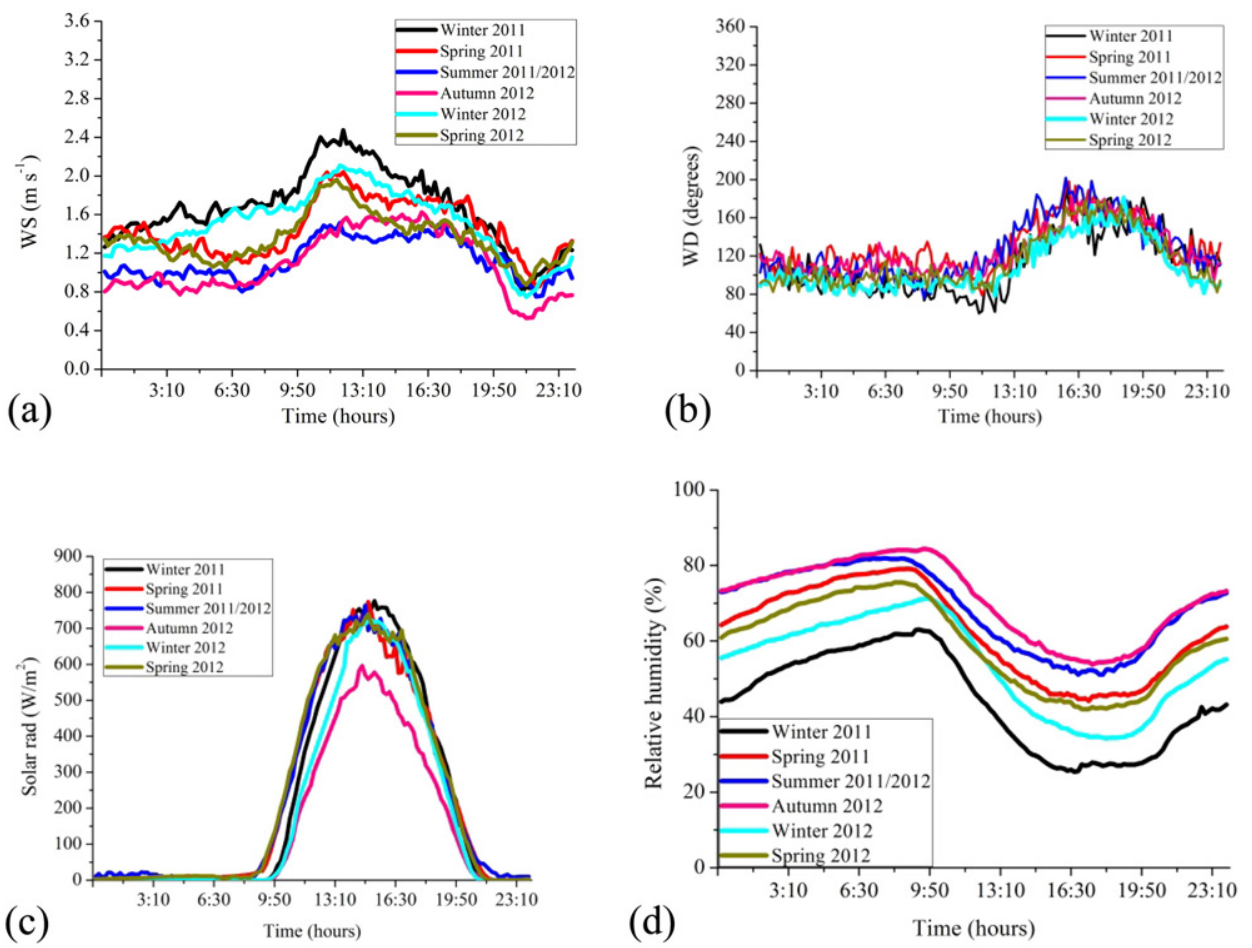

Fig. 3. Meteorological conditions for the different seasons studied: (a) wind direction; (b) wind speed; (c) solar radiation flux; (d) relative humidity.

particles due to gas phase reactions, because there was a much smaller surface area of existing aerosols available for gas absorption. The more humid conditions during the summer should also have favored the nucleation of new particles (Jaecker-Voirol and Mirabel, 1989) and the stabilization of condensed compounds such as $\mathrm{NH}_{4} \mathrm{NO}_{3(\mathrm{~s}, \text { aq) }}$ or $\mathrm{NH}_{4} \mathrm{Cl}_{(\mathrm{s} \text {, aq) }}$ (Stelson and Seinfeld, 1982; Pio and Harrison, 1987), for which the deliquescence relative humidities (at $298^{\circ} \mathrm{C}$ ) are 61.8 and $80.0 \%$, respectively (Seinfeld and Pandis, 1998). Such conditions often occur during the daytime in summer, but not in winter.

Fig. 6 shows the ratios of the number concentrations of aerosols in the three size ranges for the period between August 2011 and November 2012, based on monthly average concentrations, revealing the consistently higher contribution of the nucleation mode particles during the summer period. Previous work has shown that this could be attributed to lower concentrations of aerosols in larger size fractions (up to $10 \mu \mathrm{m}$ ) and higher humidity during the rainy season favoring the nucleation of new particles (Da Rocha et al., 2005; Allen et al., 2004; Caetano-Silva et al., 2013).

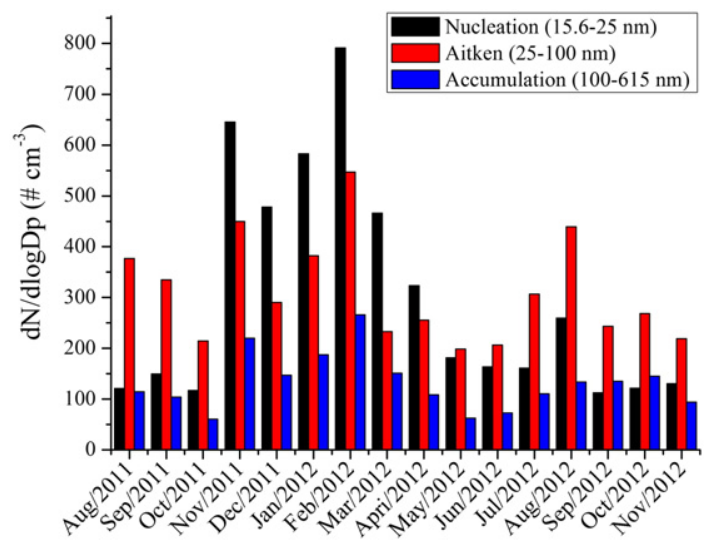

Fig. 4. Mean monthly aerosol number concentrations in the nucleation, Aitken, and accumulation size ranges for the period August 2011-November 2012

\subsection{Diurnal cycles in particle concentrations}

Higher average aerosol concentrations were observed at night than during the day, especially in the case of the smallest particles (Fig. 7). Possible explanations include: (a) reduced boundary layer depth at night, leading to the build-up of aerosols within a smaller atmospheric volume; (b) increased emissions from sugar cane burning, which normally occurs at night; and (c) growth of aerosols from smaller sizes into the measurable range.

Overall aerosol number concentrations were higher in the Aitken mode, compared to the nucleation and accumulation modes. Higher average number concentrations of nucleation and accumulation mode particles were obtained (throughout the day) for the summer period, although this was not observed for the Aitken mode. The greatest diurnal variability in number concentrations was observed for the Aitken mode, followed by the accumulation and nucleation mode particles. Nonetheless, generally similar diurnal trends were found for all particles sizes and all seasons.

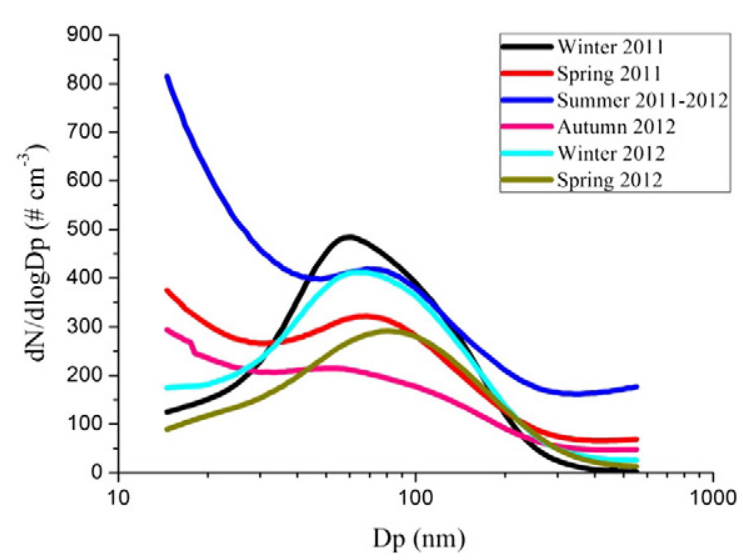

Fig. 5. Particle number size distributions according to season. 


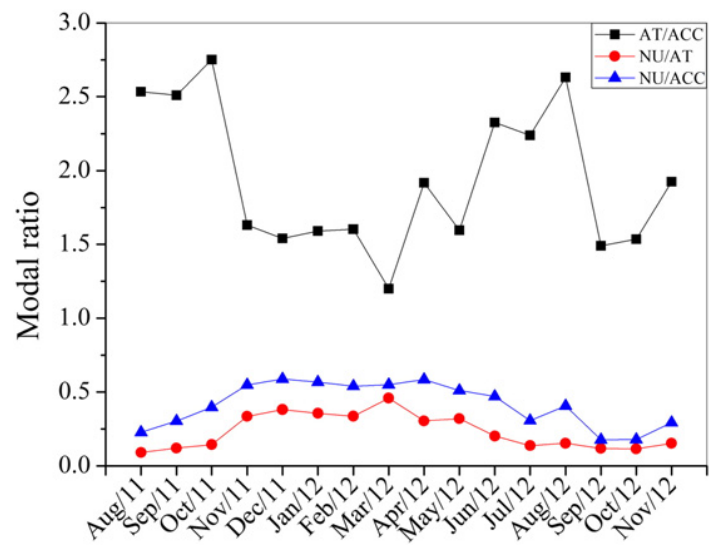

Fig. 6. Monthly ratios of the number concentrations of aerosols in three size ranges. AT: Aitken; ACC: accumulation; NU: nucleation.

Previous work found that diurnal changes in the depth of the planetary boundary layer of the study region were unable to explain the magnitude of the differences in aerosol number concentrations observed for daytime and nighttime periods (Caetano-Silva et al., 2013). The possibility that the diurnal trends observed in the present work were associated with biomass burning emissions was investigated using data for periods with or without evidence of major fires. During the period 3-4 June 2012, no fires were detected in the region. However, the ratios between nighttime maximum and daytime minimum aerosol number concentrations were similar to those observed during the remainder of June, when fires were frequently detected (Fig. 8). This suggests that freshly emitted biomass burning aerosols were not responsible for the observed diurnal trends, which were therefore probably due to the hygroscopic growth of existing particles into the detectable size range, as reported previously by Caetano-Silva et al. (2013).

There was evidence of nighttime sources of particles, because peaks in the number concentrations did not follow the same trend as $\mathrm{RH}$, and were therefore not caused by hygroscopic growth of existing particles into the detectable size range at higher humidity (Fig. 9). An interesting feature was that although the concentrations of $\mathrm{NO}_{2}$ and particle numbers tended to follow similar general trends, the peaks observed for the particle numbers and $\mathrm{NO}_{2}$ were frequently asynchronous, with an $\mathrm{NO}_{2}$ peak preceding a particle peak by up to several tens of minutes, and vice versa (Fig. 9). In contrast, synchronous inverse correlation was observed between $\mathrm{NO}_{2}$ and ozone, due to rapid titration of NO. These findings suggest that the aerosols and gas phase oxides of nitrogen $\left(\mathrm{NO}_{\mathrm{x}}\right)$ were not necessarily derived from the same sources, from which it can be inferred that secondary aerosol formation caused the observed peaks in particle number concentrations. Given the ubiquitous presence of biogenic and anthropogenic volatile (or semivolatile) hydrocarbons in the atmosphere of the study region (Allen et al., 2004), a plausible model describing the observed trends in particle number concentrations is the formation of condensable species (such as carbonyls and carboxylic acids) by reactions between hydrocarbons and radicals produced during reactions involving ozone and $\mathrm{NO}_{\mathrm{x}}$.

The data illustrated in Fig. 9 indicate that particle formation events mainly (but not exclusively) occurred during the nighttime, as well as at dawn, when the onset of photochemistry (shown by the increase in the ozone concentration) was accompanied by substantial peaks in particle number concentrations. Subsequent to the dawn events, particle concentrations decreased substantially, especially during the summer under cleaner atmospheric conditions, indicating depletion of the main particle precursor compounds (hydrocarbons). Under polluted conditions, there was almost complete loss of nucleation and Aitken mode particles during the afternoon, while there was a persistence of accumulation mode aerosols, which were therefore able to grow by gas condensation and the aggregation of smaller particles (Fig. 9a).

An important point is that ozone was never fully depleted at night, and was therefore available to participate in heterogeneous reactions as well as reactions leading to the formation of radicals capable of reacting with hydrocarbons in the gas phase. During the winter period, with intense daytime photochemistry associated with the emissions from biomass burning, ozone levels were much higher than during the summer, and nighttime ozone concentrations rarely decreased to below $10 \mathrm{ppb}$.
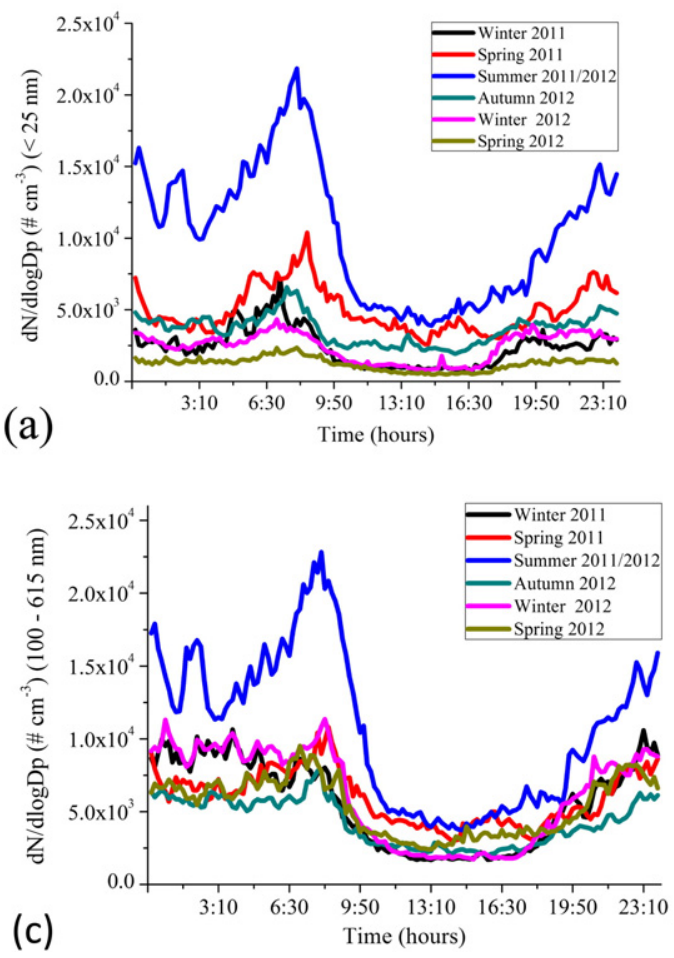

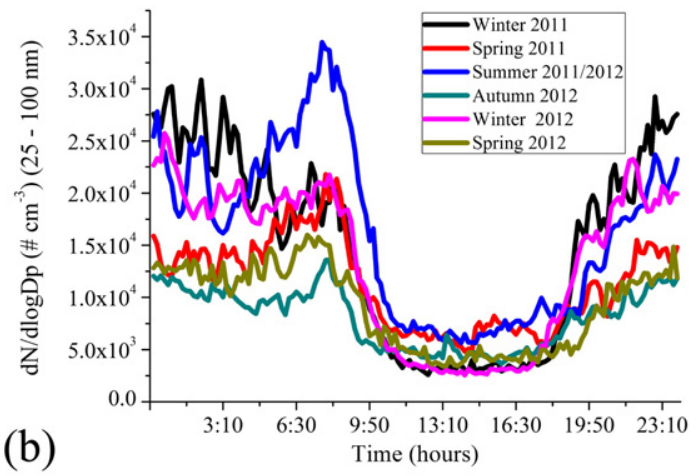

(b) 


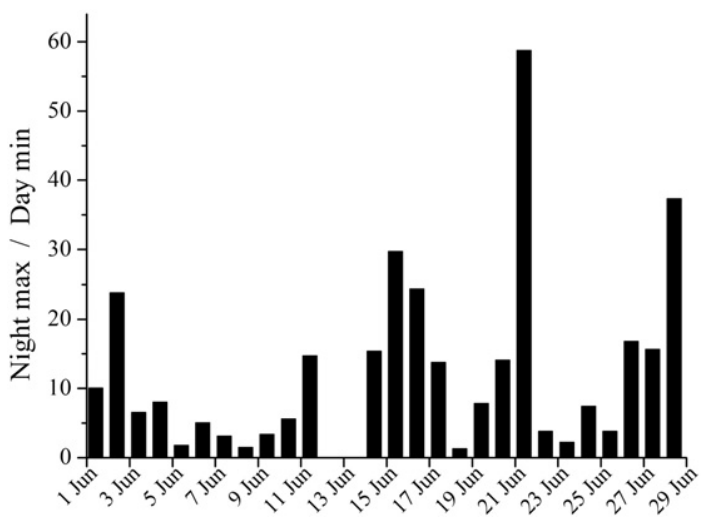

Fig. 8. Ratios between nighttime maximum and daytime minimum aerosol number concentrations for the month of June 2012.

$\mathrm{NO}_{2}$ concentrations were much lower during the daytime, due to photochemical $\mathrm{HNO}_{3}$ production (Eqs. $1 \mathrm{a}$ and $1 \mathrm{~b}$ ). In addition, turbulent mixing and expansion of the boundary layer caused by strong insolation during the daytime has been estimated to dilute the concentrations of trace components (gases and aerosols) in the lower troposphere of the study region by approximately 60\% (Caetano-Silva et al., 2013; Urban et al., 2012).

\subsection{Anthropogenic and other factors affecting aerosol size distributions}

The study region is characterized by the existence of distinct wet (summer) and dry (winter) seasons, with emissions from biomass burning mainly occurring during the dry period, while biogenic emissions are higher during the summer (Machado et al., 2008). Emissions from industrial, urban, and road transport sources remain essentially constant throughout the year. All of these sources contribute to the emission of primary particles as well as gases that are precursors to secondary aerosol species such as sulfate, nitrate, and ammonium (Allen et al., 2008; Da Rocha et al., 2005).

It has been reported previously that nitrate and sulfate are important secondary components of the aerosols present in the study region (Allen et al., 2004; Da Rocha et al., 2005), and that sugar cane burning is a major source of gases and particles released to the atmosphere, leading to the formation of secondary gas phase species such as $\mathrm{NO}_{2}$ and $\mathrm{O}_{3}$ (Oppenheimer et al., 2004; Garcia et al., 2010). Furthermore, the use of fertilizers in agriculture increases the emissions of nitrogen compounds from soils, mainly in the form of nitric oxide and ammonia (Machado et al., 2008). Reactions involving reactive gas phase nitrogen and sulfur compounds therefore exert an important influence on particle formation in the study region. During the daytime, production of the hydroxyl radical and its reaction with $\mathrm{NO}_{2}$ results in nitric acid formation (Eqs. 1a

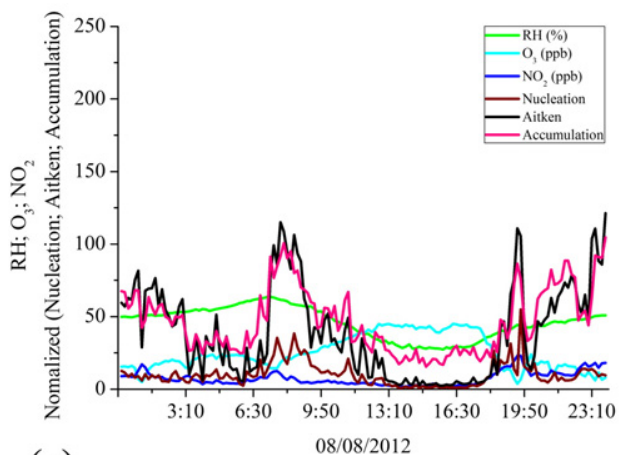

(a) and $1 \mathrm{~b}$ ), while at night, nitric acid production is initiated by heterogeneous reaction between $\mathrm{NO}_{2}$ and $\mathrm{O}_{3}$ in aqueous particles (Eqs. 2a-2c). Gas phase reactions involving $\mathrm{HNO}_{3}$ and ammonia then provide a source of new particles (Eq. 3).

$$
\begin{aligned}
& \mathrm{O}_{3}+\mathrm{h} v(\lambda<320 \mathrm{~nm})+\mathrm{H}_{2} \mathrm{O} \rightarrow 2 \mathrm{OH}+\mathrm{O}_{2} \\
& \mathrm{NO}_{2}+\mathrm{OH} \rightarrow \mathrm{HNO}_{3} \\
& \mathrm{NO}_{2}+\mathrm{O}_{3} \rightarrow \mathrm{NO}_{3} \cdot \mathrm{O}_{2} \\
& \mathrm{NO}_{2}+\mathrm{NO}_{3} \leftrightarrow \mathrm{N}_{2} \mathrm{O}_{5} \\
& \mathrm{~N}_{2} \mathrm{O}_{5}+\mathrm{H}_{2} \mathrm{O} \rightarrow 2 \mathrm{HNO}_{3} \\
& \mathrm{NH}_{3(\mathrm{~g})}+\mathrm{HNO}_{3(\mathrm{~g})} \leftrightarrow \mathrm{NH}_{4} \mathrm{NO}_{3(\mathrm{~s}, \mathrm{aq})}
\end{aligned}
$$

Gas phase reactions of $\mathrm{SO}_{2}$ lead to the formation of condensable sulfuric acid during the daytime (Eqs. $4 a-4 c$ ), while aqueous phase reactions predominate at night (Eqs. 5a-5c). The sulfuric acid produced in these reactions can then react with ammonia, mainly in the aqueous phase (Eq. 6) (Seinfeld and Pandis, 1998).

Gas phase:

$\mathrm{SO}_{2}+\mathrm{OH} \rightarrow \mathrm{HOSO}_{2}$

$\mathrm{HOSO}_{2}+\mathrm{O}_{2} \rightarrow \mathrm{HO}_{2}+\mathrm{SO}_{3}$

$\mathrm{SO}_{3}+2 \mathrm{H}_{2} \mathrm{O} \rightarrow \mathrm{H}_{2} \mathrm{SO}_{4}+\mathrm{H}_{2} \mathrm{O}$

Aqueous phase:

$$
\begin{aligned}
& \mathrm{SO}_{2}+\mathrm{O}_{3} \rightarrow \mathrm{SO}_{3}+\mathrm{O}_{2} \\
& \mathrm{HSO}_{3^{-}}+\mathrm{H}_{2} \mathrm{O}_{2} \leftrightarrow \mathrm{SO}_{2} \mathrm{OOH}^{-}+\mathrm{H}_{2} \mathrm{O} \\
& \mathrm{SO}_{2} \mathrm{OOH}^{-}+\mathrm{H}^{+} \rightarrow \mathrm{H}_{2} \mathrm{SO}_{4}
\end{aligned}
$$

Gas phase and aqueous phase:

$\mathrm{H}_{2} \mathrm{SO}_{4}+2 \mathrm{NH}_{3} \rightarrow\left(\mathrm{NH}_{4}\right)_{2} \mathrm{SO}_{4}$

The low deliquescence points of the nitrates and sulfates formed in these reactions result in rapid hygroscopic growth of aerosols containing secondary soluble species (Caetano-Silva et al., 2013).

The number size distributions of the aerosols differed according to season, reflecting the fact that nucleation processes were relatively more important in the summer, while particle growth was more important in the winter. In the winter, there was more intense biomass burning and, therefore, higher emissions of gases such as $\mathrm{NO}_{\mathrm{x}}, \mathrm{SO}_{2}$, and $\mathrm{NH}_{3}$ (especially at night, when the fires are started) as well as primary

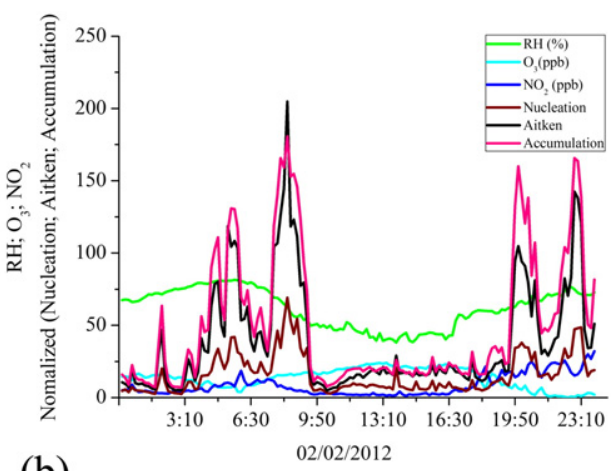

(b)

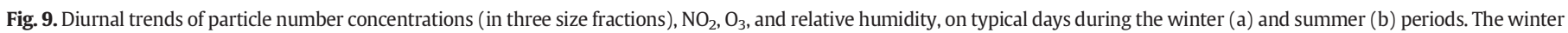
and summer were characterized by high and low ozone levels, respectively. 
aerosols (from combustion and soil resuspension) (Da Rocha et al., 2003; Machado et al., 2008; Allen et al., 2004). However, the homogeneous nucleation of new particles was inhibited in the winter, due to the greater surface area of existing aerosols available for the uptake of reactive gases.

According to the proposed model, during the daytime, high insolation and the presence of $\mathrm{NO}_{\mathrm{x}}$ and volatile organic compounds (VOCs) that had accumulated in the atmosphere during the nighttime resulted in photochemical reactions leading to ozone production (Fig. 3). These conditions favored new particle formation during the summer, when abundant growth of vegetation results in higher emissions of biogenic hydrocarbons (aerosol precursors). It has been reported previously that the concentration of organic species not only affects nucleation efficiency, but also influences the balance between nucleation and the growth of existing particles (O'Halloran et al., 2009), in agreement with the seasonal differences observed in the present work. It is also known that biomass burning in the study region is an important source of many organic compounds detected in the aerosol (Urban et al., 2016).

In the wet summer season, high emissions of ammonia have been attributed to the addition of nitrogen fertilizers to humid soils (Machado et al., 2008). The ammonia released from soils could therefore react with acidic species to form condensable salts, hence providing a source of new particles during the daytime. This is most likely to involve the formation of ammonium sulfate, for which partitioning to the gas phase is negligible, rather than volatile salts such as ammonium nitrate or ammonium chloride, and is supported by the substantial quantities of sulfate detected in the bulk aerosol (Fig. 10). At night, when relative humidity increased, both nucleation and particle growth were observed, with similar intensities.

In the dry season, only a weak daytime nucleation mode was observed and aerosol formation was dominated by the growth of existing particles. This could be explained by the greater quantities of aerosols of all sizes, which favored the incorporation of gas phase compounds within the existing particles, so that only low concentrations of gases were available for the nucleation of new particles. Given the high emissions of nitrogen oxides at night, mainly from biomass burning as well as from vehicles, substantial nighttime production of nitric acid is expected from the heterogeneous hydrolysis of $\mathrm{N}_{2} \mathrm{O}_{5}$ initiated by $\mathrm{NO}_{3}$ radicals (Eqs. 2a-2c) (Vrekoussis et al., 2006). This provides a source of nitrate-containing aerosols, which can then grow in size due to the uptake of water and the condensation of semi-volatile organic compounds derived from the same sources (Nøjgaard et al., 2012).

\subsection{Chemical analysis of soluble ions}

The concentrations of soluble ionic species measured in the collected aerosols are shown in Fig. 10. It can be clearly seen that the concentrations of potassium, calcium, nitrate, and sulfate were highest during

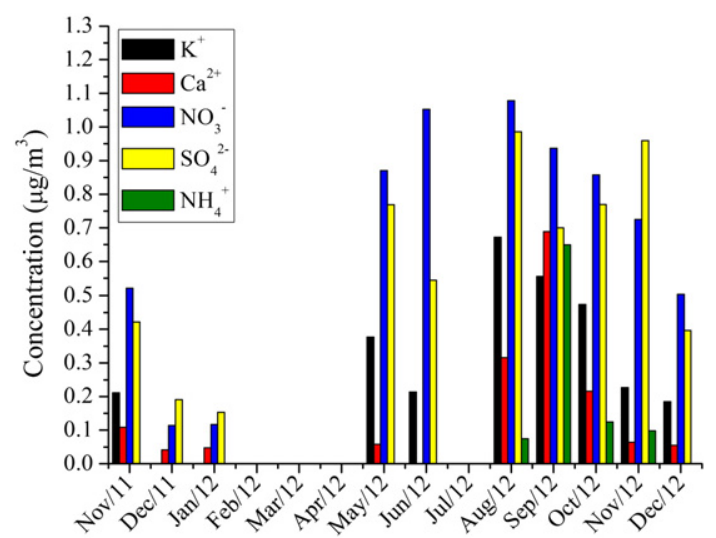

Fig. 10. Concentrations of the ions potassium, calcium, nitrate, sulfate, and ammonium in particles with average diameter $<0.49 \mu \mathrm{m}$. the sugar cane harvest period, although seasonal differences were greater for $\mathrm{K}^{+}$and $\mathrm{Ca}^{2+}$ (primary emissions from biomass burning and soil resuspension, respectively) than for $\mathrm{NO}_{3}^{-}$and $\mathrm{SO}_{4}^{2-}$ (secondary reaction products).

Previous measurements in the study region have shown that the levels of potassium salts in the aerosols increase substantially in the dry season, especially in particles smaller than $1 \mu \mathrm{m}$ (Da Rocha et al., 2005). Potassium salts have been found to act as active centers for aerosol growth, even in regions distant from recent biomass burning, such as remote areas of Amazonia, resulting in particle growth at the expense of new particle nucleation (Pöhlker et al., 2012). It is therefore likely that similar processes occurred in the present case and contributed to the removal of volatile acidic species that might otherwise have participated in aerosol nucleation.

The influence of sugar cane fires on the concentrations of the major species $\mathrm{K}^{+}, \mathrm{NO}_{3}^{-}$, and $\mathrm{SO}_{4}^{2-}$ in the aerosol $(<0.49 \mu \mathrm{m}$ size fraction $)$ can be illustrated using the concentrations measured on two days in August 2012, during the winter. On the first day (08-09/08/2012), there were 7 fire foci detected in the municipalities of Porto Ferreira and São Simão, $100 \mathrm{~km}$ upwind of the Araraquara site in a northeasterly direction (Fig. 11a). In contrast, no fires were detected upwind of the site on 29-30/08/2012 (Fig. 11b), when air masses arrived from a southerly direction. The concentration of $\mathrm{K}^{+}$measured on the day influenced by biomass burning was around four times higher, compared to the nonimpacted day, while the concentrations of $\mathrm{NO}_{3}^{-}$and $\mathrm{SO}_{4}^{2-}$ were around 2-fold higher on the impacted day (Fig. 12).

\subsection{Influence of relative humidity}

The influence of relative humidity $(\mathrm{RH})$ on particle formation due to nucleation or condensation can be illustrated by the particle number size distributions obtained for two periods in August 2012 (Fig. 13). During the first period (05/08/2012, 20:50-05:00), RH was high, in the range $69.6-89.4 \%$, and total particle numbers were low. During this period, there was clear evidence of the formation of new secondary particles, with a pronounced nucleation mode in the size distribution (Fig. 13a). In contrast, during the second period (08/08/2012, 20:5005:00), RH was low and varied in the range $43.6-59.8 \%$, particle number concentrations were higher, and the size distribution showed that aerosol formation was dominated by growth processes, with no evidence of a nucleation mode (Fig. 13b).

It is unlikely that $\mathrm{NO}_{2}$ chemistry contributed to the formation of nucleation mode particles on 05/08/2012, since homogeneous nucleation involving gas phase $\mathrm{NO}_{2}$ is driven by photochemistry (Eqs. 1a-1b) (Miyakawa et al., 2007). At night, heterogeneous processes within aqueous aerosols are mainly responsible for the formation of nitrate and sulfate in the aerosol phase (Eqs. $2 \mathrm{a}-2 \mathrm{c}, 5 \mathrm{a}-5 \mathrm{c}$ ).

Nonetheless, it has been reported that nucleation of new particles is not restricted to the daytime, and can occur at night under low condensation sink conditions (Lee et al., 2008). Rissler et al. (2006) observed higher concentrations of nucleation mode aerosols at night, compared to the daytime, in Amazonia, where there are strong emissions of biogenic hydrocarbons. Lee et al. (2008) suggested that in addition to weak condensation sinks, the presence of organic compounds could be one factor contributing to nighttime nucleation, together with lower temperatures. A possible explanation for the particle nucleation observed here at night is therefore the conversion of (semi) volatile organic compounds to less volatile water-soluble forms by reactions involving ozone or nitrate radicals (Lee et al., 2016; Alves et al., 2016).

Brown et al. (2006) suggested that an abundance of nitrogen and sulfur oxides in polluted atmospheres could lead to nighttime sulfuric acid production by reactions involving the $\mathrm{NO}_{3}$ radical and $\mathrm{SO}_{2}$. It has also been proposed that heterogeneous aqueous phase processes might occur in very small particles (Lee et al., 2008), enabling growth into the size range measured in the present work. 

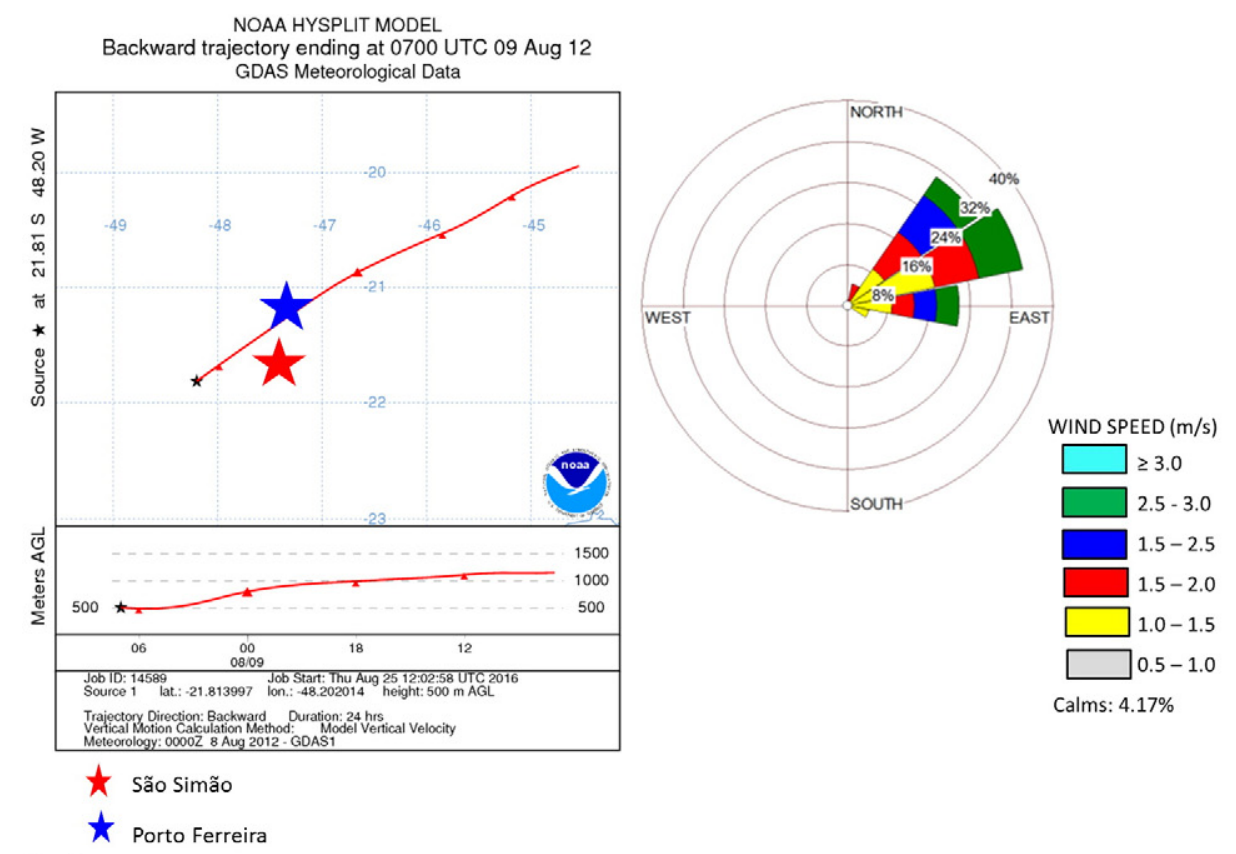

(a)

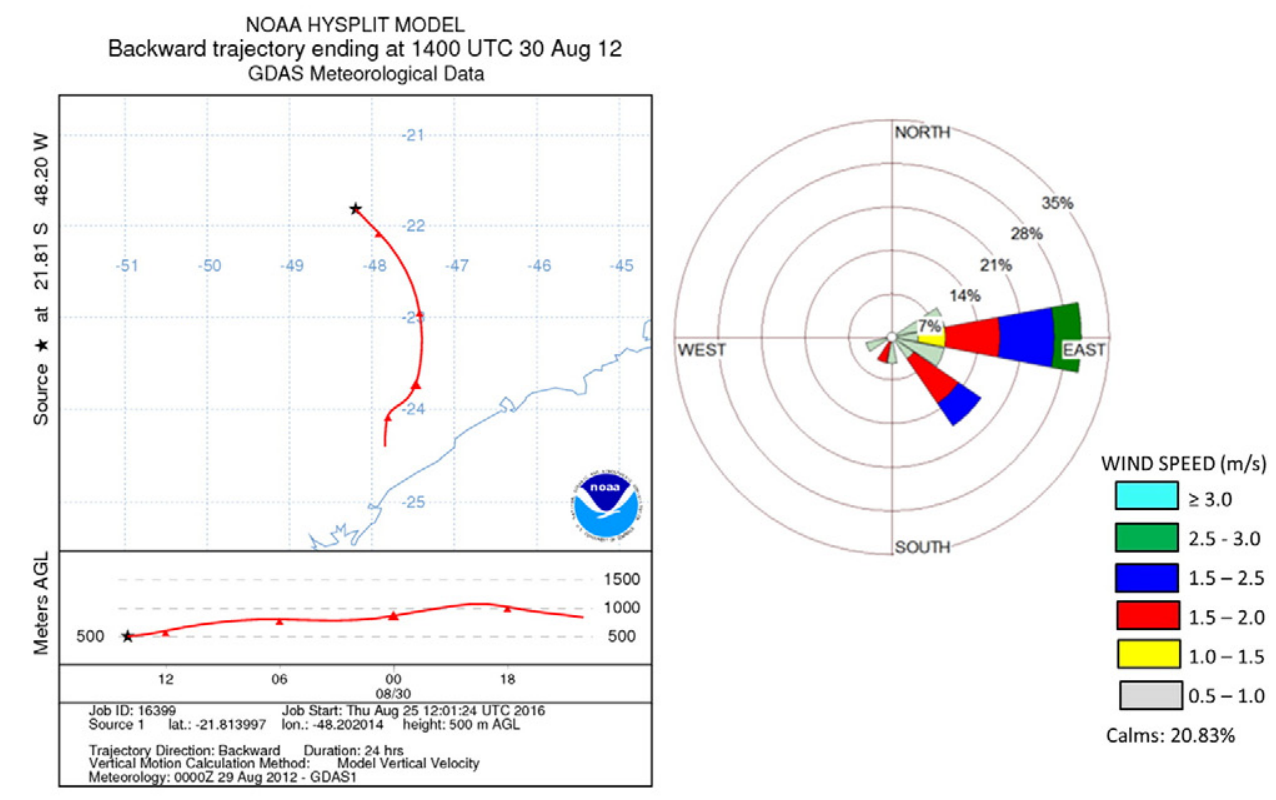

(b)

Fig. 11. Air mass back-trajectories and wind roses for days (a) when the sampling site was downwind of fire foci (08-09/08/2012), and (b) when no fire foci were detected upwind (29-30/ 08/2012).

It can be concluded from the above discussion that a low population of existing particles and/or high water vapor availability favored the formation of new particles, and that the possible reactions involved included sulfuric acid formation and/or the conversion of hydrocarbons to more soluble compounds.

During the summer, the particle size distributions were indicative of nucleation both at night $(\mathrm{RH}>47.2 \%)$ and during the daytime $(\mathrm{RH}$ $>25.7 \%$ ), while a peak centered at around $80 \mathrm{~nm}$ showed that condensation processes were more intense at night than during the daytime. Typical daytime and nighttime size distributions obtained in February 2012 are illustrated in Fig. 13(c) and (d).
In winter, during the daytime (when RH was below 27.3\%), only condensational aerosol growth was observed, as illustrated in Fig. 13 (e) for two daytime periods in August 2012. This could be attributed to the existence of a high total aerosol surface area available for the condensation of gas phase species, favoring this process rather than the nucleation of new particles.

\section{Conclusions}

The findings presented in this work enable the proposal of a plausible model to explain the observed trends in particle number 


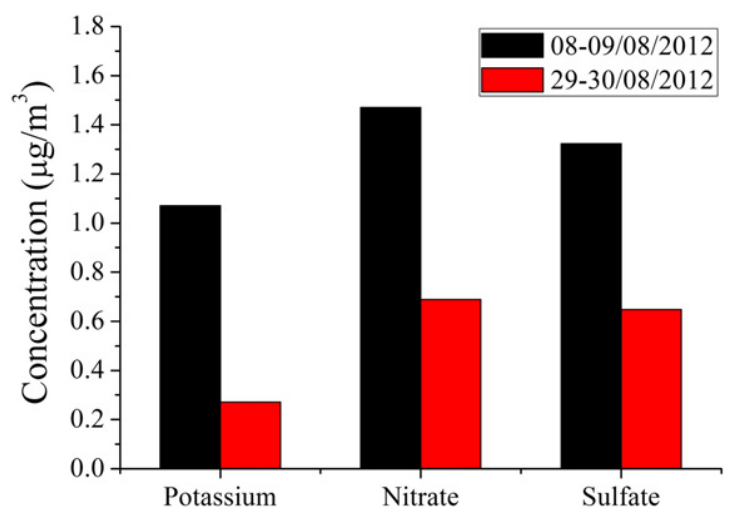

Fig. 12. Concentrations of $\mathrm{K}^{+}, \mathrm{NO}_{3}^{-}$, and $\mathrm{SO}_{4}^{2-}$ on days when the sampling site was downwind of fire foci (08-09/08/2012), and when no fire foci were detected upwind (29-30/08/2012).

concentrations. This is based on the formation of condensable species resulting from reactions between hydrocarbons and radicals produced during reactions involving ozone and $\mathrm{NO}_{\mathrm{x}}$. According to
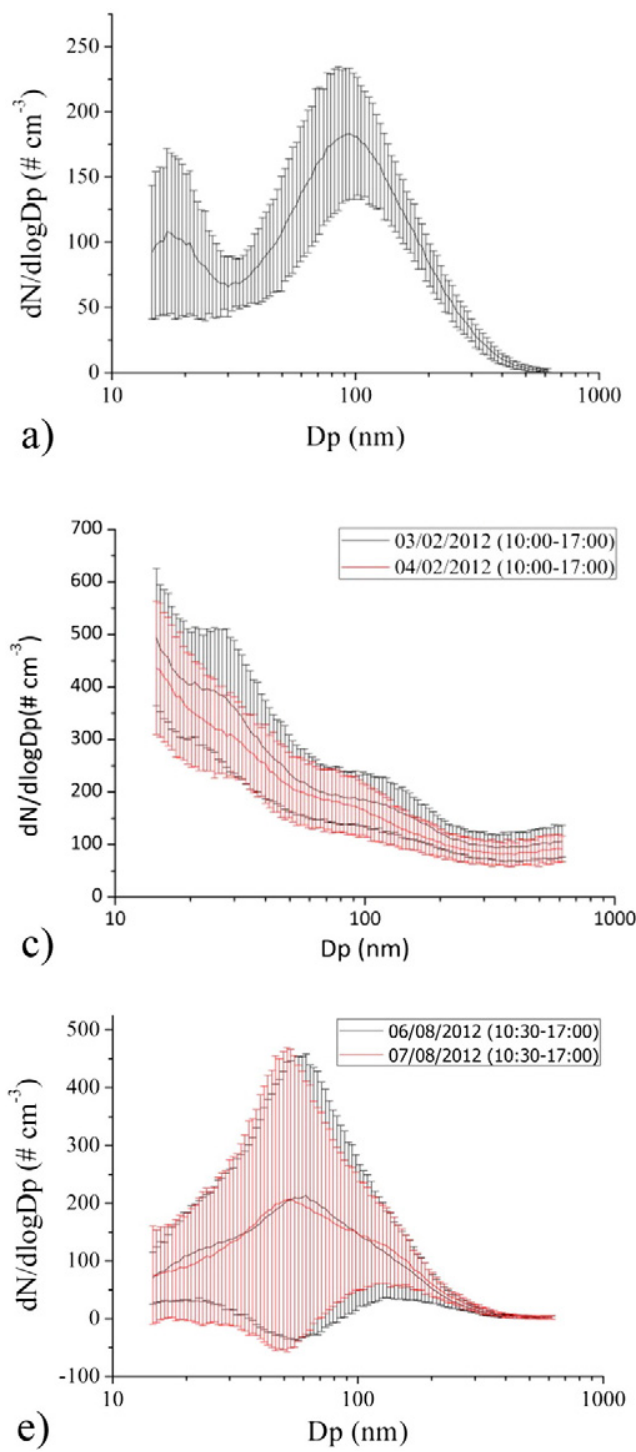

this model, during the daytime, high insolation and the presence of $\mathrm{NO}_{\mathrm{x}}$ and volatile organic compounds (VOCs) accumulated in the atmosphere during the nighttime led to photochemical reactions and ozone production. These conditions favored new particle formation during the summer, associated with a relatively small population of existing particles and high emissions of biogenic hydrocarbons as aerosol precursors. In contrast, during the winter, aerosol formation involved the condensational growth of existing particles, due to the rapid scavenging of reactive gas phase species. Strong emissions from biomass burning in the winter contributed to seasonal differences characterized by preferential occurrence of heterogeneous nucleation during the winter and homogeneous nucleation during the summer, associated with particles in the Aitken and nucleation size ranges, respectively.

\section{Acknowledgements}

The authors thank the Brazilian agencies FAPESP (grant no. 2008/ 58073-5) and CNPq (grant no. 162766/2011-4) for financial support of this work.
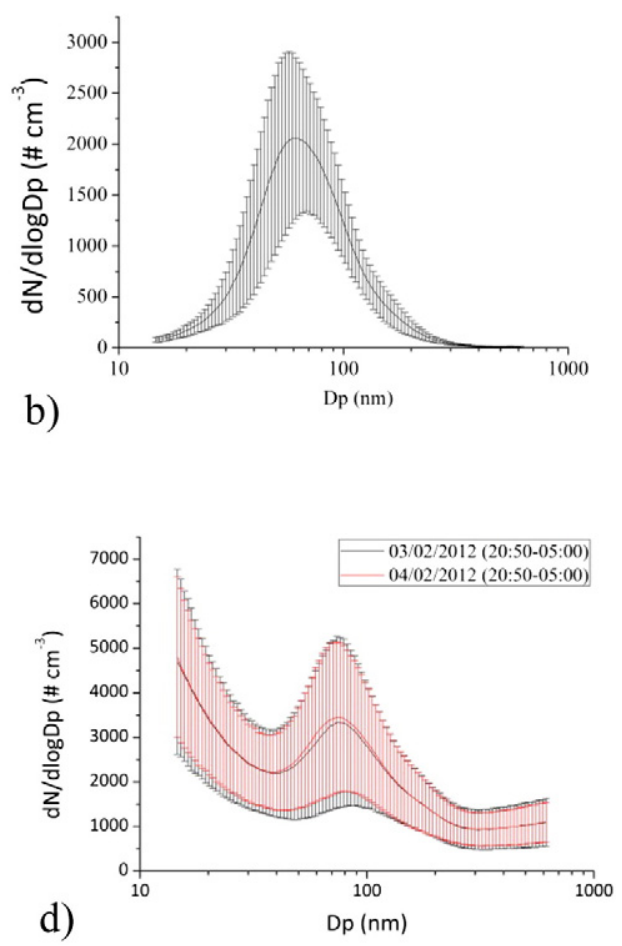

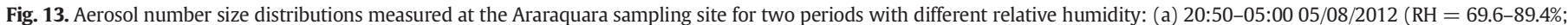

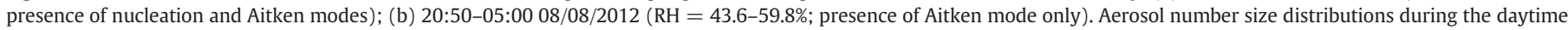

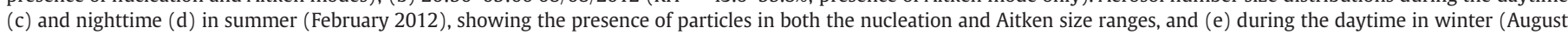
2012), showing the presence of an Aitken mode alone. The shaded areas indicate the standard deviations of the measurements. 


\section{References}

Allen, A.G., Da Rocha, G.O., Cardoso, A.A., 2004. Influence of sugar cane burning on aeroso soluble ion composition in southeastern Brazil. Atmos. Environ. 38, 5025-5038.

Allen, A.G., Da Rocha, G.O., Cardoso, A.A., Paterlini, W.C., 2008. Atmospheric particulate polycyclic aromatic hydrocarbons from road transport in southeast Brazil. Transp. Res. Part D: Transp. Environ. 13, 483-490.

Allen, A.G., Cardoso, A.A., Wiatr, A.G., Machado, C.M.D., Paterlini, W.C., Baker, J., 2010. Influence of intensive agriculture on dry deposition of aerosol nutrients. J. Braz. Chem. Soc. 21 (1), 87-97.

Alves, D.K.M., Kummrow, F., Cardoso, A.A., Morales, D.A., Umbuzeiro, G.A., 2016. Mutagenicity profile of atmospheric particulate matter in a small urban center subjected to airborne emission from vehicle traffic and sugar cane burning. Environ. Mol. Mutagen. 57, 41-50.

Andreae, M.O., Crutzen, P.J., 1997. Atmospheric aerosols: biogeochemical sources and role in atmospheric chemistry. Science 276, 1052-1058.

Brown, S.S., Ryerson, T.B., Wollny, A.G., Brock, C.A., Peltier, R., Sullivan, A.P., Weber, R.J. Dubé, W.P., Trainer, M., Meagher, J.F., Fehsenfeld, F.C., Ravishankara, A.R., 2006. Variability in nocturnal trinogen oxide processing and its role in regional air quality. Science 311, 67-70.

Caetano-Silva, L., Allen, A.G., Lima-Souza, M., Cardoso, A.A., Campos, M.L.A.M., Nogueira, R.F.P., 2013. Analysis of diurnal cycles in the mass of ambient aerosols derived from biomass burning and agro-industry. J. Geophys. Res. - Atmos. 118, 1-13.

Da Rocha, G.O., Franco, A., Allen, A.A., Cardoso, A.A., 2003. Source of atmospheric acidity in an agricultural-industrial region of São Paulo State, Brazil. J. Geophys. Res. 108, 1-11.

Da Rocha, G.O., Allen, A.G., Cardoso, A.A., 2005. Influence of agricultural biomass burning on aerosol size distribution and dry deposition in southeastern Brazil. Environ. Sci. Technol. 39, 5293-5301.

Garcia, G., Allen, A.G., Cardoso, A.A., 2010. Development of a sensitive passive sampler using indigotrisulfonate for the determation of tropospheric ozone. J. Environ. Monit. 12, 1325-1329.

Hegg, D.A., Radke, L.F., Hobbs, P.V., 1990. Particle production associated with marine clouds. J. Geophys. Res. 95, 13917-13926.

Holmes, N.S., 2007. A review of particle formation events and growth in the atmosphere in various environments and discussion of mechanistic implications. Atmos. Environ. 41, 2183-2201.

Ichoku, C., Kahn, R., Chin, M., 2012. Satellite contributions to the quantitative characterization of biomass burning for climate modeling. Atmos. Res. 111, 1-28.

Jaecker-Voirol, A., Mirabel, P., 1989. Heteromolecular nucleation in the sulfuric acid-water system. Atmos. Environ. 23, 2053-2057.

Kan, H., Chen, R., Tong, S., 2012. Ambient air pollution, climate change, and population health in China. Environ. Int. 42, 10-19.

Korhonen, P., Kulmala, M., Laaksonen, A., Viisanen, Y., McGraw, R., Seinfeld, J.H., 1999. Ternary nucleation of $\mathrm{H}_{2} \mathrm{SO}_{4}, \mathrm{NH}_{3}$, and $\mathrm{H}_{2} \mathrm{O}$ in the atmosphere. J. Geophys. Res. 104 26349-26353.

Kulmala, M., 2003. How particles nucleate and grow. Science 302, 1000-1001.

Kulmala, M., Pirjola, L., Mäkelä, J.M., 2000. Stable sulphate clusters as a source of new atmospheric particles. Nature 404, 66-69.

Kulmala, M., Vehkamäki, H., Petäjä, T., Dal Maso, M., Lauri, A., Kerminen, V.-M., Birmili, W., McMurry, P.H., 2004. Formation and growth rates of ultrafine atmospheric particles: a review of observations. J. Aerosol Sci. 35, 143-176.

Kulmala, M., Kontkanen, J., Junninen, H., Lehtipalo, K., Manninen, H.E., Nieminen, T., Petäjä, T., Sipilä, M., Schobesberger, S., Rantala, P., Franchin, A., Jokinen, T., Järvinen, E., Äijälä, M., Kangasluoma, J., Hakala, J., Aalto, P.P., Paasonen, P., Mikkilä, J. Vanhanen, J., Aalto, J., Hakola, H., Makkonen, U., Ruuskanen, T., Mauldin III, R.L. Duplissy, J., Vehkamäki, H., Bäck, J., Kortelainen, A., Riipinen, L., Kurtén, T., Johnston, M.V., Smith, J.N., Ehn, M., Mentel, T.F., Lehtinen, K.E.J., Laaksonen, A., Kerminen, V.M., Worsnop, D.R., 2013. Direct observations of atmospheric aerosol nucleation. Science 339, 943-946.

Laakso, L., Mäkelä, J.M., Pirijola, L., Kulmala, M., 2002. Model studies on ion-induced nucleation in the atmosphere. J. Geophys. Res. - Atmos. 107 (D20). http://dx.doi.org/10 1029/2002JD002140.

Lee, S.-H., Young, L.-H., Benson, D.R., Suni, T., Kulmala, M., Junninen, H., Campos, T.L., Rogers, D.C., Jensen, J., 2008. Observations of nighttime new particle formation in the troposphere. J. Geophys. Res. 113, D10210. http://dx.doi.org/10.1029/2007JD009351.
Lee, A.K.Y., Abbatt, J.P.D., Leaitch, W.R. Li, S.-M., Sjostedt, S.J., Wentzell, J.J.B., Liggio, J., Macdonald, A.M., 2016. Substantial secondary organic aerosol formation in a coniferous forest: observations of both day- and nighttime chemistry. Atmos. Chem. Phys. $16,6721-6733$.

Lei, H., Wuebbles, D.J., 2013. Chemical competition in nitrate and sulfate formations and its effect on air quality. Atmos. Environ. 80, 472-477.

Machado, C.M.D., Cardoso, A.A., Allen, A.G., 2008. Atmospheric emission of reactive nitrogen during biofuel ethanol production. Environ. Sci. Technol. 42, 341-385.

Miyakawa, T., Takegawa, N., Kondo, Y., 2007. Removal of sulfur dioxide and formation of sulfate aerosol in Tokyo. J. Geophys. Res. 112, D13209. http://dx.doi.org/10.1029/ 2006JD007896.

Nøjgaard, J.K., Nguyen, Q.T., Glasius, M., Sørensen, L.L., 2012. Nucleation and Aitken mode atmospheric particles in relation to $\mathrm{O}_{3}$ and $\mathrm{NO}_{\mathrm{x}}$ at semirural background in Denmark. Atmos. Environ. 49, 275-283.

O'Halloran, T.L, Fuentes, J.D., Collins, D.R. Cleveland, M.J., Keene, W.C. 2009. Influence of air mass source region on nanoparticle events and hygroscopicity in central Virginia, U.S. Atmos. Environ. 43, 3586-3595.

Oppenheimer, C., Tsanev, V.I., Allen, A.G., Mcgonigle, A.J.S., Cardoso, A.A., Wiatr, A., Paterlini, W., Dias, C.M., 2004. $\mathrm{NO}_{2}$ emissions from agricultural burning in São Paulo, Brazil. Environ. Sci. Technol. 38, 4557-4561.

Pio, C.A., Harrison, R.M., 1987. The equilibrium of ammonium chloride aerosol with gaseous hydrochloric acid and ammonia under tropospheric conditions. Atmos. Environ. $21,1243-1246$

Pöhlker, C., Wiedemann, K.T., Sinha, B., Shiraiwa, M., Gunthe, S.S., Smith, M., Su, H., Artaxo, P., Chen, Q., Cheng, Y., Elbert, W., Gilles, M.K., Kilcoyne, A.L.D., Moffet, R.C., Weigand, M., Martin, S.T., Pöschl, U., Andreae, M.O., 2012. Biogenic potassium salt particles as seeds for secondary organic aerosol in the Amazon. Science 337, 1075-1078.

Rissler, J., Vestin, A., Swietlicki, E., Fisch, G., Zhou, J., Artaxo, P., Andreae, M.O., 2006. Size distribution and hygroscopic properties of aerosol particles from dry-season biomass burning in Amazonia. Atmos. Chem. Phys. 6, 471-491.

Rosenfeld, D., Lohmann, U., Raga, G.B., O'Dowd, C.D., Kulmala, M., Fuzzi, S., Reissell, A., Andreae, M.O., 2008. Flood or drought: how do aerosols affect precipitation? Science 321, 1309-1313.

Seinfeld, J.H., Pandis, S.N., 1998. Atmospheric Chemistry and Physics: From Air Pollution to Climate Change. John Wiley, New York, pp. 507-519.

Singh, A., Dey, S., 2012. Influence of aerosol composition on visibility in megacity Delhi. Atmos. Environ. 62, 367-373.

Stelson, A.W., Seinfeld, J.H., 1982. Relative humidity and temperature dependence of the ammonium nitrate dissociation constant. Atmos. Environ. 16, 983-993.

Unica, 2013. http://www.unica.com.br/noticia/38156175920320868796/colheitamecanizada-de-cana-produz-queda-nas-emissoes-de-gases-causadores-do-efeitoestufa/ (accessed 18/07/2016).

Urban, R.C., Lima-Souza, M., Caetano-Silva, L, Queiroz, M.E.C., Nogueira, R.F.P., Allen, A.G. Cardoso, A.C., Held, G., Campos, M.L.A.M., 2012. Use of levoglucosan, potassium, and water-soluble organic carbon to characterize the origins of biomass-burning aerosol. Atmos. Environ. 61, 562-569.

Urban, R.C., Alves, C.A., Allen, A.G., Cardoso, A.A., Campos, M.L.A.M., 2016. Organic aerosols in a Brazilian agro-industrial area: speciation and impact of biomass burning. Atmos. Res. 169, 271-279.

Vrekoussis, M., Liakakou, E., Mihalopoulos, N., Kanakidou, M., Crutzen, PJ., Lelieveld, J. 2006. Formation of $\mathrm{HNO}_{3}$ and $\mathrm{NO}_{3}$ in the anthropogenically-influenced eastern Mediterranean marine boundary layer. Geophys. Res. Lett. 33, L05811. http://dx.doi.org/ 10.1029/2005GL025069.

Vuollekoski, H., Nieminen, T., Paasonen, P., Sihto, S.-L., Boy, M., Manninen, H., Lehtinen, K. Kerminen, V.-M., Kulmala, M., 2010. Atmospheric nucleation and initial steps of particle growth: numerical comparison of different theories and hypotheses. Atmos. Res. 98, 229-236.

Zhao, H., Tong, D.Q., Gao, C., Wang, G., 2015. Effect of dramatic land use change on gaseous pollutant emissions from biomass burning in Northeastern China. Atmos. Res. 153, 429-436.

Zhu, J., Xia, X., Che, H., Wang, J., Zhang, J., Duan, Y., 2016. Study of aerosol optical properties at Kunming in southwest China and long-range transport of biomass burning aerosols from North Burma. Atmos. Res. 169, 237-247. 